\title{
Overcoming Challenges of Education Sector in Indonesia Through Positive Psychology
}

\author{
Jamalul Muttaqin \\ Master of Islamic Educational Psychology, Universitas Islam Negeri Sunan Kalijaga
}

Submitted 31 December 2019 Accepted 14 October 2020 Published 28 June 2021

\begin{abstract}
Challenges of education sector in Indonesia are complex. Literature on Indonesia education has shown these challenges relate to learners, educators, and administrators. We often see, in certain places such as remote areas, poor management of education system from the quality of to human resources. Consequently, this poor education quality led to student's low motivation and eventually creating the image of education in Indonesia as appeared dreary. This article aims to discuss positive psychology to contextualize challenges of Indonesia's education. I argue that positive psychology offers insights of overcoming education challenges that might lead to a more joyful educational process. The study is a literature-based research through critical and comprehensive analysis of the phenomenon of education in Indonesia. This research emphasizes that positive psychology works have a very influential space to help achieving welfare of those involve in the education sector. The result offers few recommendations through finding new methods or models of learning that are pleasing that attempt to motivate students to apply positive psychology to improve their quality of life.
\end{abstract}

Keywords: education in indonesia; students; positive psychology

\section{Introduction}

One of the fundamental challenges of education sector in Indonesia date back in the early establishment of Indonesia as a sovereign nation. The Indonesian Constitution 1945, later amended in 2001, guarantees the right of all citizens to education, which is reiterated in few legislations on education system, among others is the latest National Education System Act 2003. In the Constitution, the goal of education in the contemporary context is to develop the ability to live and work for the country and the nation. This foundation strengthens the commitment of the Indonesian people to be able to rise up from the lack of education after more than three centuries of being colonized by the Dutch. This education is none other than a fundamental legacy of Dutch colonialism (Finkelstein, 1951).

${ }^{1}$ Address for correspondence: jejenaqin@gmail.com 
Later progress has not seen the journey of education as dreamt by the nation's founders. In 2013, data from UNESCO stated that Indonesia was ranked 121 out of 185 countries in terms of the quality of its education, and was ranked the second-lowest in the world in 2015 (Programme for International Student Assessment [PISA], 2013). The Director of Primary Education Teachers, Ministry of Education and Culture states that our education system is under resource, with shortage of around 735,000 teachers particularly in remote areas. In the National Social Economy (Susenas) in 2015, it was recorded that 5.3 million children aged 7-18 years did not enjoy school system. The figure later decreasing to 4.6 million children, which sparks optimism. Nevertheless, there remains a total of 187,828 students in Indonesia who are not accessing school.

Indonesia education is also painted with the issue of violence and bullying. A survey released by the National Commission for Child Protection (KPAI) in 2012 recorded that 87.6 percent of the 1,026 participants surveyed reported that they were bullied both physically and verbally at school. More recent statistics from KPAI in 2018 revealed that out of the 161 cases of child abuse it received up to May 30, 2018, around 22.4 percent involved intimidation. Khidhir (2019) as written in The ASEAN Post revealed a staggering figure of 90 percent of Year 4 (primary) to Year 8 (high school) are victims of bullying. Further from Khidhir (2019), 10 percent of Indonesian students leave school because of bullying, and 71 percent of Indonesian students consider bullying as a problem in their school, while. Issues of violence at school lead to casualties, with suicide cases in Indonesia rank eighth among ASEAN countries. In 2016, the World Health Organization (WHO) revealed that around 10,000 people committed suicide in a year. In the following year, suicide deaths in Indonesia reached 7,355 or $0.44 \%$ of the total deaths (Zulfikar \& Tarahita, 2018).

KPAI, in their data released, notes that within 9 years period, from 2011-2019, there were 37,381 complaints of violence against children. Meanwhile, for cases of bullying, the figure reached 2,473 reports. That number continues to encounter a significant increase. The Minister of Defense who highlighted the problem of radicalism, according to the results of a survey conducted in October 2019, stated that around 23.4 percent of radicalism was targeted at university students and 23.3 percent at high school students.

Problems above are among many that indicate challenges with the education system, whether it concerns the teachers, the students, or the teaching and learning process, or others. The world of education is very complex, but the character of students as a determinant of the level of educational progress is more important to be paid attention to together, especially by the government. This article was built up by these unrest in the community as we are seeing these recent cases, of which many are crucial and very concerning problems.

The problems faced in general are related to the quality of education. It can be understood from challenges presented earlier that education in Indonesia is experiencing a fundamental problem of stagnation, and cannot deliver students to feel the joy of a happy world of education. All of that can relate to the learning process in the classroom, 
teachers, and the learning atmosphere. The education spaces can be felt by students comfortably when the system works well. Student satisfaction, in positive psychology theory, according to an American psychologist, Seligman, is nothing but paying close attention to students' emotional patterns for their development and growth (Seligman et al., 2009).

When the education system does not work well, it is very possible to create a quality of education that is not good either. As a result, the educational curriculum cannot work effectively. All problems unwittingly spread to the students who cannot feel comfortable learning in the classroom. Students will feel the learning process as an unpleasant space because it is confused by an incorrect educational curriculum system. During this time, the educational curriculum created in Indonesia has always contained political elements. Every time the minister changes, the education curriculum system will also change. As a result, the problem of education is increasingly complex, and its direction is increasingly erratic (Muchtarom, 2013). Since Indonesia's independence in 1945, the educational curriculum has changed several times, namely in 1947, 1952, 1962, 1968, 1975, 1984, 1994, 2004, 2006, and 2013 (Gershon, 2011; Mukminin et al., 2019).

The 2013 curriculum aims to improve the quality of teaching in schools, mainstream and religious, or known as madrasas, throughout Indonesia by focusing on achieving an optimal balance between the development of cognitive skills, particularly critical thinking and problem solving, and the development of student character and behavior. In fact, many media cover cases of intimidation that cause death or physical and emotional injury to students (Djiwandono, 2016; Konishi et al., 2010) The 2015 Global School-based Student Health Survey (GSHS) noted that in Indonesia 20.6 percent of students aged 13-17 were abused on one or more days for 30 days. Of those surveyed, 24.1 percent male and 17.4 percent female reported being bullied (WHO, 2015). In 2015, National Commission for Child Protection (KPAI) announced that while child abuse cases were decreasing, cases of children being bullied were increasing, and bullying had started happening in primary schools (Aulia, 2016).

At the 2019 National Education Day Commemoration ceremony (Hardiknas), the Ministry of Research, Technology, and Higher Education emphasized that they want to build competitive, innovative, and character human resources. Nasir instructed in facing the industrial revolution 4.0 and society 5.0, humanitarian affairs are very important. The development of student character is a priority in order to be able to uphold truth, honesty, justice, virtue, responsibility, and love for the country. This question will lead to a very long, theoretical, and revolutionary answer when it collides with the problem of education in Indonesia. The discourse on the mental revolution heralded by the President since 2015 has shown no signs of improvement at all. Jokowi's Nawacita (nine priority missions) to prioritize the acceleration of development infrastructure in connecting the periphery areas with growth centers, and promoting connectivity between islands in the archipelago may be a means of advancing education in remote areas (Salim \& Negara, 2018). 
Therefore, so far, psychology tends to be interpreted as an epistemology of science dealing with psychological problems and psychological disorders experienced by students and teaching staff. Although, since the emergence of this theory, psychology has been applied almost to various educational problems, from the study of the learning process on individuals, overcoming learning difficulties to pedagogy. In practice, psychology, in western schools, has a very important position to change the students' mindset that tends to liberate. The mindset, according to Herbart, is a major problem for psychology. Forming a mindset is changing the learning mindset. While thought occurs in most people, in pre-behavioral times as central to learning, orientation looks promising for educational psychology (Phillips, 1976). Because a student is not an adult even though he has senses, instincts, views of truth, beliefs, emotions, and feelings towards objects. They have little in common with adult behavior. This is where the fundamental difference is when positive psychology has to enter into the line of life in general in the world of education to change the mentality to be a human being who can think positively.

To overcome the problem of education in Indonesia in general, this article is presented as an alternative solution to raise and to break down the emotional order leading to improvement individually and in groups. Positive psychology wants to break through a single point of attention in an attempt to explore and develop character from the side of human strength (promotion of character strength). Exploring and developing the individual or group side will lead the individual or group to positive thinking to get authentic happiness which is able to function optimally in life (Seligman, 2004). Green (2014) states in terms of increasing resilience; "suggests that positive education be defined as the application of well-being science into an educational setting aimed at increasing the resilience and well-being of students, staff, and whole-school community."

Research on positive psychology in overcoming educational problems is still rarely carried out in Indonesia. Although there has been much attention on positive psychology in the literature worldwide, however majority depict a broad discussion with only few that focuses on the study of the world of education. One of which is written by Baker et al. (2017), which discusses the theory and practice of early childhood education with positive psychology. In addition, there is also a paper from Miloseva and Marelja (2009), which discuss the need for teachers to enter the classroom with a disposition that focuses on individual strengths and to understand how the diversity of students' abilities and backgrounds contributes to the subjective well-being of the student population.

Positive psychology strives to identify all student abilities. Some papers in Indonesia are only written on a number of blogs and social media such as Akhmad Sudrajat, and a paper on "Positive Psychology Applications in School Contexts" written by Farah Aulia in 2015, a student of Master of Psychology at Universitas Gadjah Mada in a Psychology Seminar and Humanity. In this paper, she uses a positive psychology approach to change this paradigm by focusing more on the unique characteristics of each student and efforts to maximize their potential. This epistemological framework that was formed was not yet strong and well known by the public. Herein lies a fundamental 
difference from several other studies when psychology is even more daring to carry out contextualization of a greater sense of reading the problems of education in Indonesia.

In this article, the problems of educational discourse that occur in Indonesia will be discuss from a positive psychological approach in the application of positive emotions, which Seligman (2004) divided into three elements; positive emotions of the past, positive emotions of the present, and positive emotions of the future. it is hoped that this discussion can form the world of education that is not merely seen as empty formal classes bounded in a rigid system. The presence of positive psychology, as written by Maslow (1943), is a motivation that moves dynamically and continuously (Pajares, 2001). Seligman and other positive psychologists are not the only scholars who belief that education should aim for the well-being of students or humanizing humans. Philosophers, such as Aristotle, has considered happiness as the ultimate goal of education (Kristjánsson, 2012).

\section{Discussion}

Education is the heart of civilization. Education cultivates human potential to give birth to real humans. The main purpose of education is solely to humanize humans because humans have power and meaningful life. Therefore, education should develop potential and make life not stressful, but happy and enjoyable. In line with what was said by Thomas Jefferson and Aristotle, that getting happiness means that it can raise selfawareness. Seligman (2002) justified that happiness is to find the meaning of one's own life substantially. The meaning of life can be obtained through the connection of other people, or future generations, or something that goes beyond itself. Self-meaning can be identified by recognizing one's own abilities and then transferring them or channeling them to something of greater benefit (Seligman et al., 2009). Happiness can be advantageous to seek life satisfaction, and well-being, aspiring to increase the individual's more complex-flexible and highly dynamic constructs (Scorsolini-Comin et al., 2013). The difference between positive psychology and traditionalist psychology is a matter of approach focus. Traditional psychology focuses on healing mental illness and weakness in people, whereas positive psychology focuses on correcting negative things and promoting positive things (Seligman \& Csikszentmihalyi, 2000).

The positive psychology initiated by Martin Seligman is considered a movement as well as a new powerful breakthrough in the world of psychology. It seems very powerful and has a vast influence. Positive psychology even spreads its wings not only in the field of psychology, but also penetrates into various other fields of science, such as psychiatry, education, leadership, management, economics and business, and even into politics and the military world. This movement succeeded in changing the face of psychological science with great passion, which attracted researchers to apply positive psychology to various fields of science. Seligman, who became President of the American Psychological Association in 1997, presented positive psychology through a scientific approach that 
integrates with other disciplines, such as genetics, neuroscience, and cognitive science, to understand happiness in depth.

The focus of the discussion of positive psychology studies carried out by Seligman (2002) is on virtues and strengths. According to him, referring to Aristotle, virtues, and strengths are human nature or essence that moves humans to always lead to happiness and goodness. The presence of psychology offers a new paradigm that other sciences have initially neglected. One of which is about positive emotions - in traditional psychologyconsidered a by-product when a person achieves goals and overcomes difficulties. Positive emotions are the key to opening the mind (broadening the mind), building resources (building), and building optimal personal development (flourishing) (Fredrickson, 2004). Departing from that, Seligman divides the types of positive emotions based on time, namely positive emotions about the past (forgiveness and gratitude), positive emotions about the present (mindfulness and flow), and positive emotions about the future (optimism and hope). The three frameworks of positive emotions graded by Seligman can certainly provide a solution color in the world of education.

Indeed, overcoming a problem is not as easy as turning your palm. Let alone a problem that is closely related to something complex. Complex in the sense of being linked between one system and another, for example, the world of education in general. Seligman's framework of positive emotions also does not necessarily ignore negative emotions in humans. Even though in reality, emotions tend to want something good such as hope, honesty, gratitude, and others. On the other hand, one cannot ignore negative emotions unilaterally. Positive and negative will continue to work together to solve problems, so that one of which cannot be ignored. There is nothing wrong with giving more attention to the positive (Folkman \& Moskowitz, 2003). However, this article will employ three series of positive emotions in relation to the contextualization of educational problems in Indonesia. The following will discuss the resistance of positive psychology with three models of emotional development according to Seligman:

\section{Past Positive Emotions; Gratitude, and Character Strengths}

Sometimes people unconsciously are trapped in the euphoric puddle of modernism, obsessed with the spoil of the future, and thinking about things that will come long before the event occurs. It is as if they are living in fantasies created by themselves by imagining and then drifting into the fun so that time flies too quickly. As a result, the present cannot be enjoyed and appreciated while the past cannot be pondered and grateful for. Meanwhile, the targets planned were not achieved because they were too busy thinking about the future. The positive emotions of the past actually wanted to present grateful personalities who do not condemn past unkindness and not indulge in daydreams and unfulfilled desires. In this condition, he or she should have remained full of joy with what had happened. Scientifically, gratitude has a very good effect on health, even gratitude is an inner attitude of a person (state of mind, state of heart). 
The notion of gratitude is a form of gratitude when receiving the good things (kindness, compassion, love), or help from unexpected people (Mccullough et al., 2002) This definition requires further accepted explanation. Of course, there are other parties involved when someone does gratitude. It can be other people, God, or others because it is a social thing. However, not all gifts can be pleasant. According to research conducted by Tsang (2007) sometimes a gift makes a person feel inferior and feel indebted to the giver so that the desire to fulfill it arises in order to restore his self-esteem.

Contextualization of positive emotions is the process of giving birth to gratitude and strength in a person so that they can be applied to the development of the world of education, whether it is to a teacher or a student. The creation of perceptions about the contribution that a person makes to us is appreciated because there are great sacrifices (Mccullough et al., 2002), Besides that, the perception that needs to be built is a good intention, because this good intention generates gratitude (Heider, 1958), considers the action to be of high value, and builds the perception that other people do not just fulfill their obligations (Emmons \& Crumpler, 2000). So, teachers or students respect each other, either appreciating the dedication of a teacher who has taught or a teacher appreciating the genuine efforts of students in learning. These instruments give birth to a more harmonious and more intimate learning atmosphere. There is no psychological stress because everything is treated in good ways.

That is why education requires empathy. Understanding other people is putting yourself in a position that can respect different beliefs from the problems that they are experiencing. If this can be applied, education must encourage young people to show an interest in a "difference" or "other people's problems" in order to be able to respect each other (Kesidou, 2019). This principle is sought to form a valuable character (not just emotion), but how gratitude becomes a permanent behavior or character (trait), as a personal identity for students or a teacher. These characters reap results that create moral strength to move each learner's personality to make a distinctive contribution from within himself. More formally, he or she is said to be a grateful personality who makes gratitude one of the guiding his life. Research conducted by Emmons and Crumpler (2002) assessed that this trait leads people to tend to be open-minded, more extroverted, and easier to socialize. That benefit is even proven medically.

The relationship between teachers and students is sometimes not harmonious, not only with students but also with relationships between teachers. For example, if teachers in the education institution deal with all matters related to administrative or nonadministrative, both employees, parents, students, and others. Generally speaking, all will be correlated so that these perceptions, if contextualized with the concept of positive psychology, must have strong interconnections in order to give birth to a moral function of gratitude that can be instilled for a teacher or student. The positive emotions of the past become a medium for self-evaluation when they want to do something for the future. The hope is that the substance of gratitude will give birth to attachment and love that are inherent as identity in shaping character strength. 


\section{Positive Emotions of The Present; Hacking the Nature of Mindfulness}

Something that often occurs at various levels of education is when people find students with a bad past, they are often avoided or even disliked. They will have no friends and will not be approached by their teachers, and will not have more attention. The example above is a problem that needs to be taken seriously in the form of a larger priority scale and giving a bigger negative effect. However, the present is real as the advice of Master Oogway in Kung Fu Panda "Yesterday is history, tomorrow is a mystery, but today is a gift and that is why it is called the present". Today the focus is merely on one of the programs, agendas, and targets to be aimed at. All must be oriented towards goals and results. That goal is driven by anxiety, dissatisfaction, and a desire for a better condition than now.

One way is with the concept of mindfulness. This concept has theoretically been proven to be able to help self-acceptance, establishing positive relationships with others, showing independence, controlling the environment, having a purpose in life, and being able to grow personally, especially when struggling with society, he or she can expect for prosperity. Mindfulness can predict the level of a person's psychological well-being (Ecclestone \& Hayes, 2009). Theoretically, mindfulness can be a potential mechanism to lead to positive change (Shapiro et al., 2006).

Through individual awareness, students are able to increase empathic behavior such as in interacting, so that awareness is important for change and better growth. In line with Grotli (in Totlund, 2014) that, if a person has the ability to see himself and be aware of behavior (acting), then this can increase awareness when dealing with other people. For example, when he acts consciously, he will be able to have a sense of empathy, love and will easily build relationships with other people (Totlund, 2014).

One of the positive attitudes born from mindfulness is non-judging, patience, beginner's mind (a beginner's point of view, there is a new outlook in life, not rigid), trust, nonstriving (not insistent, meaning not to force yourself to achieve a goal), acceptance, and letting go of everything that has happened. There is no regret.

\section{Positive Emotions of The Future; Building Optimism a la Martin Seligman.}

If someone does not have goals and hopes for the future, then his life will certainly not have strong principles and commitments. The concept of optimism is built from the opposite configuration, namely pessimism. Seligman made this breakthrough with a study on the phenomenon of learned helplessness (helplessness as a result of learning). The pessimism that appears in humans is not actually a genetic factor and not a permanent trait, but the process of learning that is created and formed with a paradigm born from within self (Gillham et al., 2001).

The principle of living with optimism can be applied in all aspects of the reality of life, including in the world of education, both instilling an attitude of optimism in students, teachers, parents, and the structure of education management. Believe it or not, research conducted by a psychologist in the Netherlands states that this optimism can make humans live longer because they avoid heart disease (Giltay et al., 2004). Optimism correlates with higher subjective well-being, even when facing a very difficult event. This 
principle creates an attitude of permanence (asking self), pervasiveness (responding to events occurring whether they are fun or not), personal (questioning the cause that happened to him whether it is something that happened to him came from within himself or outside him) (Seligman, 2006; Seligman \& Csikszentmihalyi, 2000). So that everything is evaluated whatever the weaknesses, strengths, and opportunities for him.

In a more comprehensive term, in order for life to be meaningful, it means that it must be precise to find the meaning of life by having a concrete purpose. The basic question that needs to be asked is, what exactly makes life meaningful? What is relevant to an attitude in such a way as to find that life has a point, a purpose, and a development? Interestingly, it is receiving some support from recent psychological research to show that the purpose of life is accepting things that have already happened. Logically, "the meaning of life is about connecting various events over time by integrating the past, present, and future." Hence, when someone focuses on past life's journey towards a better future by doing positive activities now, in psychology, it is defined as an optimistic person who has clear targets (Kauppinen, 2013). Humans, according to Seligman, in this case, must bear their own risks from a failure they face, no need to feel disappointed because the nature of optimism deep in the human soul has been trained by accepting reality in the form of gratitude and sincerity(Krueger, 2012).

According to Seligman, who has recently formulated positive psychology, prosperity comes from the pursuit of five successful endeavors: Positive emotions, Engagement, Relationships, Meaning, and Achievement. Those five foundations create a structure of integrity, for example, positive emotions involving feelings of pleasure, happiness, and fulfillment, including pleasure, joy, ecstasy, warmth, and comfort. Commitment engagement is fully absorbed in the activity that continues to flow in humans, whereas the meaning of involving a feeling is that one's existence is a goal, even though the meaning is often framed by religion or spirituality, and achievement refers to a sense of accomplishment and success in pursuit of something that is aimed at or aspired to (Park, 2015).

However, this far, education that has developed in Indonesia is still concerned with the discourse of curriculum development through a character education approach that has not firmly provided a methodology for achieving that direction such as the abolishment of the National Examination, which will take effect in the 2020/2021 school year. This is based on Law Number 20 of 2003 concerning the National Education System and Permendikbud No. 20 of 2018 concerning Strengthening Character Education (PPK). Herein lies a mistake that needs to be corrected together because psychology should be involved in understanding child development. Since the emergence of Darwin's Origin of Species after Herbart, developmental psychology has become important, especially in knowing student activities. Through this knowledge, a new paradigm in psychology, such as positive psychology, is the only new method to reach student welfare because all character forms were created from an early age. The reason is, the teacher must understand the sequence of mental development and how it grows gradually. Because the child is a passive vessel into which knowledge should be poured out and calls for what he 
describes as directed growth, which involves the child's own activity and spontaneous interest in the learning process. The mind is connected to the body and activity is the receiving center of all knowledge (Baldwin, 1895).

If positive psychology is truly presented in Indonesian education, stakeholders will face many challenges. Actually, the positive psychology approach also includes characterbuilding more broadly and thoroughly. From there, incomprehension will arise when the school pays less attention to the positive school cultures, even it often leads to the inadequacy of students and teachers in developing their potential. Eventually, positive school cultures have negative impacts on the development of potential teachers at work. How to Build Positive School Culture? This question is a tough challenge to solve together. Because school culture plays a role in developing student achievement through main values and supporting values, such as achievement values, discipline, cleanliness, religion, and character (Zeidan et al., 2010). The biggest problem is the lack of evaluation and then controlling, and the inaccurate management of education (Close \& AmreinBeardsley, 2018). To achieve all of this, it can be started by involving positive psychology education in the context of education in Indonesia because to this time, psychology has rarely been used to change a mindset and to build a characterized personality. At that point, positive psychology is also important in the development of character education in Indonesia.

\section{Conclusion}

As the heart of civilization, education is very important. Looking at the general problems that occur in Indonesia, Martin Seligman's concept of positive psychology theory presented in this article provides at least three theoretical substances. The concept refers to three sets of emotions divided into time frames: positive emotions of the past, positive emotions of the present, and positive emotions of the future. The quality of education is seen from the quality of the students, while the quality of the students is seen from how the education space can deliver students to be better. The characters built by the positive psychological theory are instilling gratitude (a person who is grateful and accepts reality), mindfulness (a person who focuses on what he is aiming for), and optimism (selfconfidence, evaluating what happened to his life). 


\section{Acknowledgement}

The author would like to thank Dr. Hj. Casmini, S.Ag., M.Si. who had provided guidance starting from the study design, data collection, revision, and writing process.

\section{Funding}

The author did not receive any financial support for the study as it is a part of research assignment at Interdisciplinary Islamic Studies Program of Islamic Educational Psychology UIN Sunan Kalijaga, Yogyakarta.

\section{Author's Contribution}

The author designed, analyzed data, and wrote manuscript independently.

\section{Conflict of Interests}

The author declares no conflict interest in writing process of the manuscript.

\section{Orcid ID}

Jamalul Muttaqin https://orcid.org/0000-0003-2013-8640

\section{References}

Aulia, F. (2016). Bullying experience in primary school children. SCHOULID: Indonesian Journal of School Counseling, 28-32. http://dx.doi.org/10.23916/schoulid.v1i1.37.28-32

Baker, L., Green, S., \& Falecki, D. (2017). Positive early childhood education: Expanding the reach of positive psychology into early childhood. European Journal of Applied Positive Psychology, 1, 8.

Baldwin, J. M. (1895). Mental development in the child and the race: Methods and processes. Macmillan.

Close, K., \& Amrein-Beardsley, A. (2018). Learning from what doesn't work in teacher evaluation. Phi Delta Kappan, 100(1), 15-19. https://doi.org/10.1177/0031721718797115

Djiwandono, P. I. (2016). Character education in content courses: Self-scoring as a means for developing honesty in students. TEFLIN Journal, 27(2), 153-165. http://dx.doi.org/10.15639/teflinjournal.v27i2/153-165

Ecclestone, K., \& Hayes, D. (2009). Changing the subject: The educational implications of developing emotional well-being. Oxford Review of Education, 35(3), 371-389. https://doi.org/10.1080/03054980902934662

Emmons, R. A., \& Crumpler, C. A. (2000). Gratitude as a human strength: Appraising the evidence. Journal of Social and Clinical Psychology, 19(1), 56-69. https://doi.org/10.1521/jscp.2000.19.1.56

Finkelstein, L. S. (1951). Education in Indonesia. Far Eastern Survey, 20(15), 149-153. https://doi.org/10.2307/3023860

Folkman, S., \& Moskowitz, J. T. (2003). Positive psychology from a coping perspective. Psychological Inquiry, 14(2), 121-125. 
Fredrickson, B. L. (2004). The broaden-and-build theory of positive emotions. Philosophical Transactions of the Royal Society of London. Series B, Biological Sciences, 359(1449), 13671378. https://dx.doi.org/10.1098/rstb.2004.1512

Gershon, W. S. (2011). Introduction: Towards a sensual curriculum. Journal of Curriculum Theorizing, 27(2), 1-16.

Gillham, J. E., Shatté, A. J., Reivich, K. J., \& Seligman, M. E. P. (2001). Optimism, pessimism, and explanatory style. In E. C. Chang (Ed.), Optimism E pessimism: Implications for theory, research, and practice (p. 53-75). American Psychological Association. https://doi.org/10.1037/10385-003

Giltay, E. J., Geleijnse, J. M., Zitman, F. G., Hoekstra, T., \& Schouten, E. G. (2004). Dispositional optimism and all-cause and cardiovascular mortality in a prospective cohort of elderly Dutch men and women. Archives of General Psychiatry, 61(11), 11261135. https://doi.org/10.1001/archpsyc.61.11.1126

Heider, F. (1958). The psychology of interpersonal relations. John Wiley \& Sons, Inc.

Kauppinen, A. (2013). Meaning and happiness. Philosophical Topics, 41(1), 161-185. https://doi.org/10.5840/philtopics20134118

Kesidou, A. (2019). Preparing educators and researchers for multicultural/intercultural education: A Greek perspective. In W. Veugelers (Ed.), Education for Democratic Intercultural Citizenship, (p. 148-165). Brill.

Khidhir, S. (2019). Bullying in Indonesia. The ASEAN Post. Retrieved from https://theaseanpost.com/article/bullying-indonesia

Konishi, C., Hymel, S., Zumbo, B. D., \& Li, Z. (2010). Do school bullying and studentteacher relationships matter for academic achievement? A multilevel analysis. Canadian Journal of School Psychology, 25(1), 19-39. https://doi.org/10.1177/0829573509357550

Kristjánsson, K. (2012). Positive psychology and positive education: Old wine in new $\begin{array}{llll}\text { bottles? } & \text { Educational } & \text { Psychologist, } & \text { 47(2), }\end{array}$ https://doi.org/10.1080/00461520.2011.610678

Krueger, J. I. (2012). Seligman's flourish: The second coming. The American Journal of Psychology, 125(1), 121-124. https://doi.org/10.5406/amerjpsyc.125.1.0121

Maslow, A. H. (1943). A theory of human motivation. Psychological Review, 50(4), 370-396. https://doi.org/10.1037/h0054346

Mccullough, M. E., Emmons, R. A., \& Tsang, J.-A. (2002). The grateful disposition: A conceptual and empirical topography. Journal of Personality and Social Psychology, 82(1), 112-127. https://doi.org/10.1037//0022-3514.82.1.112

Miloseva, L., \& Marelja, J. (2009). Toward an applied positive psychology in inclusive education. Iskanja (Vzgoja-Pre-Vzgoja), 35/36, 49-57.

Muchtarom, M. (2013). Islamic education in the context of Indonesia national education. Jurnal Pendidikan Islam, 28(2), 323-338. https://doi.org/10.15575/jpi.v28i2.551

Mukminin, A., Habibi, A., Prasojo, L. D., Idi, A., \& Hamidah, A. (2019). Curriculum reform in Indonesia: Moving from an exclusive to inclusive curriculum. Center for Educational Policy Studies Journal, 9(2), 53-72. https://doi.org/10.26529/cepsj.543 
Pajares, F. (2001). Toward a positive psychology of academic motivation. The Journal of Educational Research, 95(1), 27-35. https://doi.org/10.1080/00220670109598780

Park, C. L. (2015). Integrating positive psychology into health-related quality of life research. Quality of Life Research, 24(7), 1645-1651. https://doi.org/10.1007/s11136$\underline{014-0889-\mathrm{Z}}$

Phillips, S. (1976). The contributions of psychology to education. Oxford Review of Education, 2(2), 179-196.

Programme for International Student Assessment (PISA). (2013). PISA 2012 results in focus: What 15-year-olds know and what they can do with what they know. Organisation for Economic Co-operation and Development (OECD). Retrieved from https://www.oecd.org/pisa/keyfindings/pisa-2012-results-overview.pdf

Salim, W., \& Negara, W. S. D. (2018). Infrastructure development under the Jokowi administration: Progress, challenges and policies. Journal of Southeast Asian Economies, 35(3), 386-401. https://doi.org/10.1355/9789814843102-012

Scorsolini-Comin, F., Fontaine, A. M. G. V., Koller, S. H., \& Santos, M. A. dos. (2013). From authentic happiness to well-being: The flourishing of Positive Psychology. Psicologia: Reflexão e Crítica, 26(4), 663-670. https://doi.org/10.1590/S0102-79722013000400006

Seligman, M. E. P., \& Csikszentmihalyi, M. (2000). Positive psychology: An introduction. American Psychologist, 55(1), 5-14. https://doi.org/10.1037/0003-066X.55.1.5

Seligman, M. E. P. (2004). Authentic happiness: Using the new positive psychology to realize your potential for lasting fulfillment. Simon and Schuster.

Seligman, M. E. P. (2006). Learned optimism: How to change your mind and your life. Vintage Books.

Seligman, M. E. P., Ernst, R. M., Gillham, J., Reivich, K., \& Linkins, M. (2009). Positive education: Positive psychology and classroom interventions. Oxford Review of Education, 35(3), 293-311. https://doi.org/10.1080/03054980902934563

Shapiro, S. L., Carlson, L. E., Astin, J. A., \& Freedman, B. (2006). Mechanisms of mindfulness. Journal of Clinical Psychology, 62(3), 373-386. https://doi.org/10.1002/jclp.20237

Totlund, M. (2014). Leadership development program - useful? Which influence/impact have leadership development programs had to your development as a leader? [Master's thesis, Norges Teknisk-Naturvitenskaplige Universitet]. NTNU Open. https://ntnuopen.ntnu.no/ntnu-xmlui/handle/11250/299106

Tsang, J.-A. (2007). Gratitude for small and large favors: A behavioral test. The Journal of Positive Psychology, 2(3), 157-167. https://doi.org/10.1080/17439760701229019

World Health Organization (WHO). (2015). Global School-based Student Health Survey: Indonesia 2015 fact sheet. World Health Organization. Retrieved from https://www.who.int/ncds/surveillance/gshs/2015 Indonesia GSHS Fact Sheet.pdf

Zeidan, F., Johnson, S. K., Diamond, B. J., David, Z., \& Goolkasian, P. (2010). Mindfulness meditation improves cognition: Evidence of brief mental training. Consciousness and Cognition, 19(2), 597-605. https://doi.org/10.1016/j.concog.2010.03.014 


\section{MUTTAQIN II POSITIVE PSYCHOLOGY}

Zulfikar R. M., \& Tarahita, D. (2018). Some facts about suicide in Indonesia. International Policy Digest. Retrieved from https://intpolicydigest.org/2018/10/01/some-factsabout-suicide-in-indonesia 